\title{
The Use of Particle Size Spectra in Determining the Structure of a Plankton Community*
}

\author{
T. R. PARSONS**
}

\begin{abstract}
The earliest studies on plankton were largely confined to descriptive taxonomy. Later, chemical studies produced quantitative measurements of plankton biomass, and data from these studies have been employed to build mathematical models describing the dynamics of plankton communities.

More recently a need has been expressed (e.g. Margalef, 1957; PATten, 1959) to add a new concept to plankton studies. Ideally this concept requires that the organization or structure of a plankton community should be expressed in terms of the actions of all species present on each other. In practise the problem is to obtain an adequate quantitative expression of community structure, preferably without having to return to the tedium of taxonomic studies. The use of particle size spectra determined electronically will be discussed as a possible method for providing data for models based on biomass production, as well as in providing data on community structure.
\end{abstract}

\section{Introduction}

The purpose of this presentation is to discuss the value of particle size spectra as a technique which may assist in the understanding of plankton communities. The technical details of the procedure used in our laboratory have been described previously (SHELDON and PARSONS, 1967a and $\mathrm{b}$ ), and while other techniques may eventually prove more accurate and easier to apply (see PARSONS and SEKI, 1969b, for discussion), I believe that the general ecological utility of the approach can now be clearly demonstrated.

In examining the role of particle size spectra for the study of plankton communities, it may be worthwhile to refer briefly to the historical development of research on plankton. In doing this, it would be impossible to review all the early and contemporary works in this field. In the following account, therefore, I have chosen certain references only because they serve as good examples of the type of research carried out during a particular period.

Most of the earliest publications on plankton were concerned with taxonomic studies on the

* Received April 7, 1969

** Fisheries Research Board of Canada, Pacific Oceanographic Group, Biological Station, Nanaimo, B.C. occurrence and abundance of different species (e.g. Cleve, 1883; Karsten, 1905; Allen, 1922). Starting in the 1920's, and particularly in the 1930's, there was a great increase in the number of publications dealing with the chemistry of plankton, and more especially with inorganic micronutrients in seawater (e.g. ATKINS, 1923; HARVEY, 1928; RAKESTRAW, 1936; MiYAKE, 1939). With the advent of some quantitative data on plankton biomass and nutrients, it was possible by about 1940 for scientists to construct mathematical models of plankton production (e.g. Fleming, 1939; Riley, 1917; SteEle, 1956). Techniques used to collect data on biomass and production improved during the next decade (e.g. NIELSEN, 1952), but by the late 1950's the limitations of mathematical models of production were being recognized (e.g. MARGALEF, 1957), and a need was expressed for more information on the plankton community, not only in terms of its total biomass and production, but also in terms of its structure. The ultimate need in this direction is perhaps best expressed by HAIRSTON (1959) who wrote: ". . the most satisfying means of expressing community organization would be through directly observed actions of all species present upon each other". This still appears to be a somewhat idealized ecological desideratum. However, it is at least 
in part the purpose of this presentation to discuss how our knowledge of a plankton community may be improved towards this goal.

Attempts to improve our understanding of plankton communities using more recent and diversified chemical techniques have added to the total extent of our knowledge, but they have contributed little that is new in concept. While a great deal of chemical data must still be collected, especially on growth, assimilation and nutritive value of the predators and prey in a plankton community (for example, studies such as those of SHIRASHI and PROVASOLI, 1959 and CONOVER, 1966), the most urgent need appears to be for methods of obtaining information which will broaden our concept of plankton communities. The answer to this problem may lie in being able to express community structure in quantitative terms, and perhaps the chief proponent of this idea has been MARGALEF (1957, 1958, and 1968; see also PATTEN, 1959 and 1961). Among biological oceanographers, however, there has been a strong tendency to describe plankton communities in terms of total production at diflerent levels (i.e. primary, secondary, etc.), and to express measurement $\mathrm{s}_{\mathbf{S}}$ in terms of absolute units of weight, volume and time. While these measurements are necessary, it is also apparent that they do not in themselves tell us very much about community structure. The problem here is analogous to having to develop a method which would quantitatively describe the complexity of a jigsaw puzzle. In this respect taxonomic data are applicable to describing structure, but as MARGALEF (1968) has said, "The propaganda against old and reliable taxonomy has been very effective; today, people able to identify organisms are distressingly scarce. Taxonomy is necessary even at a macroscopic level, not only in computation of diversity but also in the study of similarity between different samples of ecosystems obtained by different methods". From this statement it would appear that after some thirty years of moving away from taxonomy, the planktologist may be faced with a need to return to this tedious study in order to obtain a wider understanding of plankton communities. However, there appear to be other ways in which to des- cribe the structure of a plankton community, and one of these may be in the phytoplankton pigment ratio $\left(D_{430} / D_{665}\right)$ used by MARGALEF (1965). At the same time, it is noted that the possible use of electronic particle counters as another technique was advocated by MARGALEF in 1965, while in 1966 we presented our first data on particle size spectra at the Eleventh Pacific Science Congress (PARSONS, LEBRASSEUR and FULTON, 1967). It appears, in fact, that the technique of measuring particle size spectra may be useful in providing data for models based on biomass production, as well as in providing data on community structure.

\section{Methods}

Primary production, chlorophyll and carbon analyses were carried out according to methods described in STRICKLAND and PARSONS (1968). Temperature and salinity were measured with an in situ salinometer (Beckman). Particle size spectra were determined using a Model B Coulter Counter and a model $\mathrm{M}$ volume convertor following the method described by SHELDON and PARSONS (1967a). Plankton size categories referred to in connection with particle distributions are as follows: ultrananoplankton, $<2 \mu$; nanoplankton, $2-20 \mu$; microplankton, $20-200 \mu$ and macroplankton, 200-2,000 $\mu$ (see DUSSART, 1965, and SHELDON and PARSONS, 1967b for discussion).

Total daily solar radiation was measured with an actinograph which was calibrated with an Epply pyranometer operated by the Biological Station, Nanaimo. The extinction of light was approximated from Secchi disc readings using a relationship between the reciprocal of the Secchi depth (S. D.) and the extinction coefficient of light at $4300 \AA$. This relationship was determined from previous studies in the area as:

$$
\frac{1}{S . D .}=1.0( \pm 0.08) K_{10}^{4300}-0.09( \pm 0.02)
$$

where the variations quoted are the standard error of the slope and intercept (STEPHENS, FULTON and KENNEDY, MS 1969).

\section{Results}

Environmental conditions: Most of the data reported in this presentation were collected during 


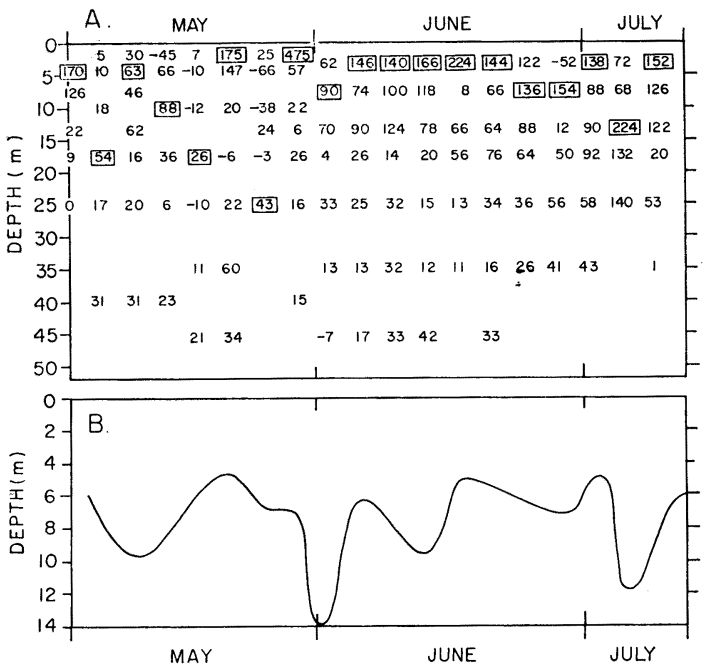

Fig. 1. (A) Changes in stability, $\frac{\partial \sigma_{t}}{\partial z} \times 10^{3}$, May July, 1968.

(B) Changes in the depth of the 24-hour average light intensity of $0.0075 \mathrm{ly} / \mathrm{min}$, May $\sim$ July, 1968. a ten-week time series study carried out from May to July, 1968, in Saanich Inlet, British Columbia $\left(48^{\circ} 35^{\prime} \mathrm{N}, 123^{\circ} 30^{\prime} \mathrm{W}\right)$. The physical oceanography of the inlet has been described by HERLINVEAUX (1962).

Samples of seawater were collected at approximately four-day intervals at a central location in the inlet. Fig. $1 \mathrm{~A}$ shows the distribution of stability with depth, the expression used being given by $\frac{\partial \sigma_{t}}{\partial z} \times 10^{3}$ (SVERDRUP et al., 1946). Maxima in these values at different depths have been marked on the figure and the data show that during May there was relatively much less stability in the water column than in June. Further it is apparent that on several occasions the depth of the surface mixed layer was well below the compensation depth, which is shown in Fig. $1 \mathrm{~B}$ as the depth of the $0.0075 \mathrm{ly} / \mathrm{min}$ isophot. The latter value was chosen as an average from studies on the compensation light

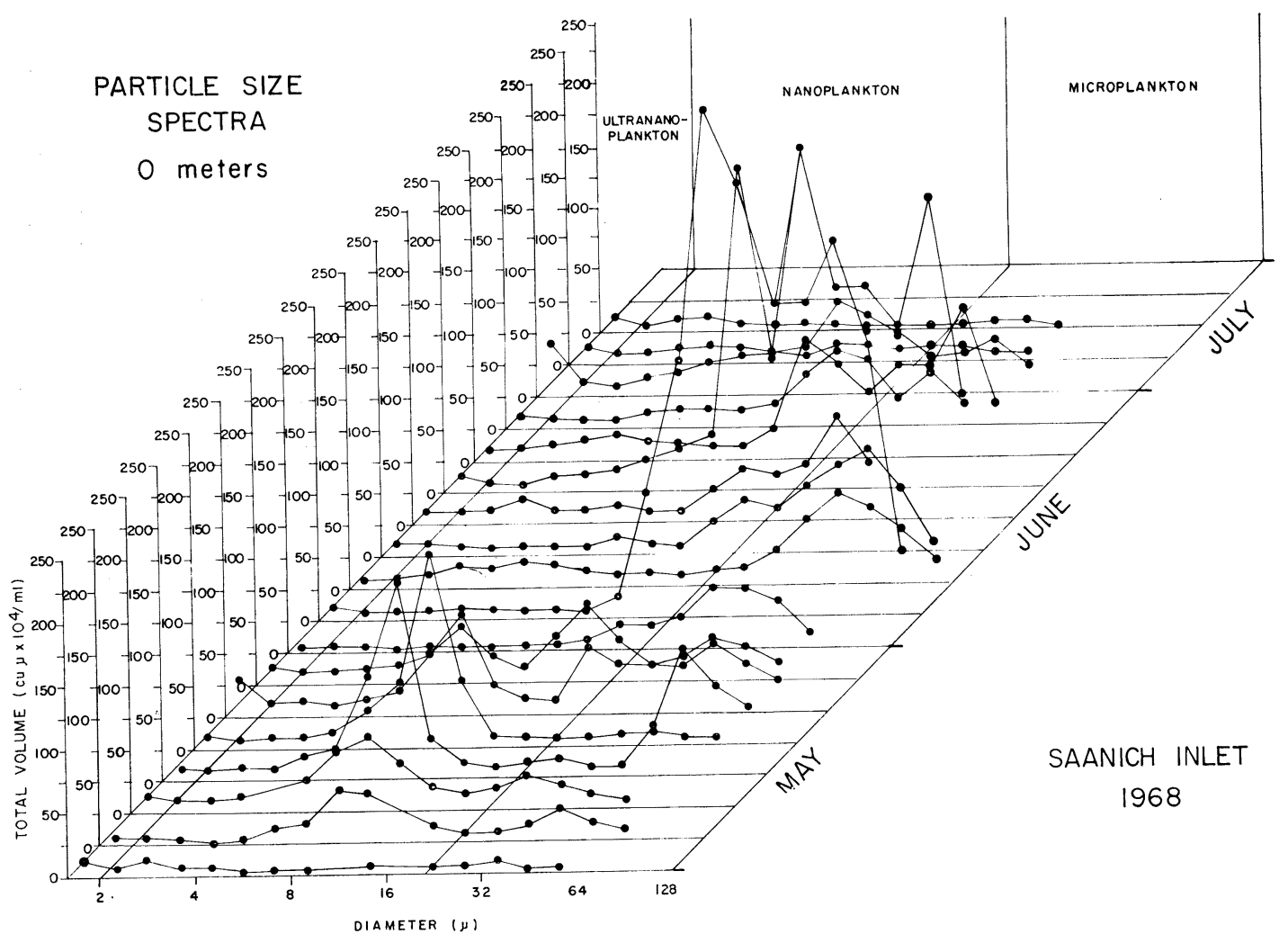

Fig. 2. Size spectra of particulate material at $0 \mathrm{~m}$ in Saanich Inlet, B. C. May July, 1968. 


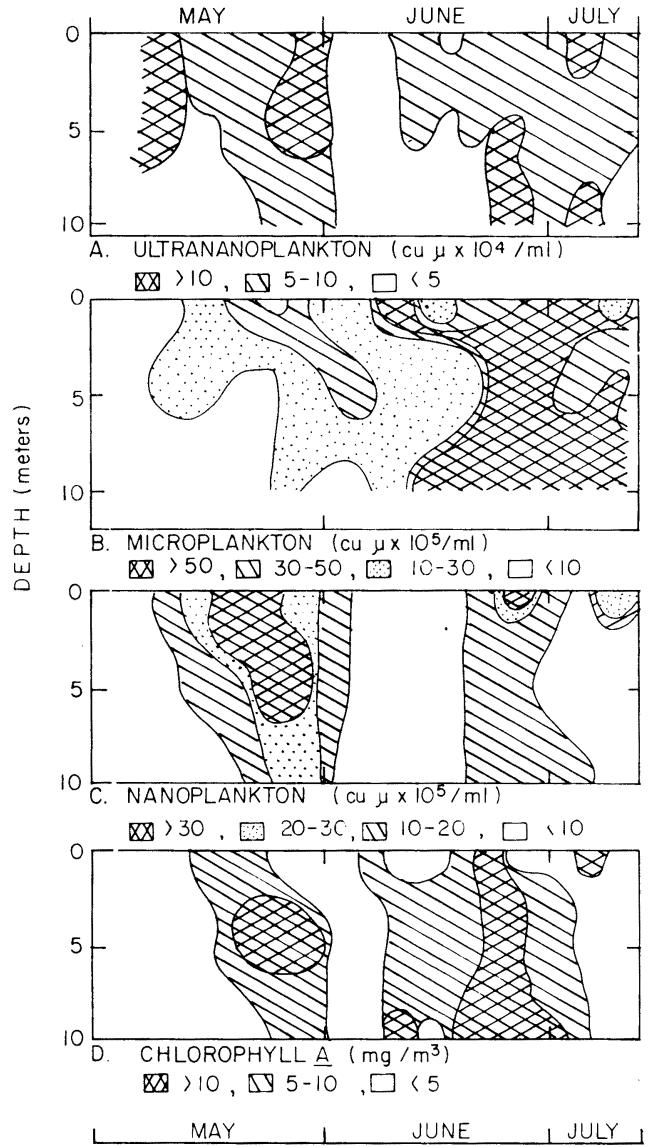

Fig. 3. Depth distribution with time of plankton size fractions and chlorophyll a, May July, 1968.

intensity made in waters adjacent to Saanich Inlet (PARSONS et al., 1969). In contrast, during most of June the water column was relatively stable and the depth of mixing was generally well above the depth of the compensation light intensity.

Particle size spectra and standing stock measurements: Fig. 2 shows changes in the size spectrum of particulate material at $0 \mathrm{~m}$ during the ten-week period in Saanich Inlet. The presentation of data in this form is difficult to follow in detail but it is intended to show primarily how the proportions of small and large particles may vary in time. Thus during the first part of May, it is apparent that the particulate material was dominated by a nanoplankton bloom (average particle diameter $c a \quad 8 \mu$ ) and that in addition to the nanoplankton, microplankton $(>20 \mu$ diameter) started to increase towards the end of May. During the first few days of June there was very little particulate material in the surface water but this was followed by a sudden and massive increase in the amount of microplankton. The microplankton bloom continued to the end of June; in addition, there was a second nanoplankton bloom toward the end of June. The ultrananoplankton $(<2 \mu$ diameter) is represented on the left-hand side of Fig. 2 but it should be recognized that due to technical limitations of the apparatus, only part of the size spectrum of these particles can be shown (see Fig. 5 in SHELdON et al., 1967), It is apparent, however, that on two occasionsat the end of May and June-there were very large increases in the quantity of ultrananoplankton.

In Fig. 3 the biomass $(\mathrm{cu} \mu / \mathrm{m} l)$ of particulate material in the three size categories shown in Fig. 2 have been totalled. In addition, similar data obtained at 5 and $10 \mathrm{~m}$ have been brought together to show the distribution with time and depth of the different size components of the plankton. (Fig. $3 \mathrm{~A}, \mathrm{~B}$ and $\mathrm{C}$ ). Fig. $3 \mathrm{D}$ shows that the distribution of chlorophyll $a$ was characterized by two maxima, one in the latter part of May and the other in the latter part of June. From Fig. $3 \mathrm{~B}$ and $\mathrm{C}$ it is apparent that the first maximum was associated with a predominance of nanoplankton, but that the highest chlorophyll values occurred during a period when there was an overlap between the distribution of nano- and microplankton. The second chlorophyll $a$ maximum was dominated by microplankton, and the highest chlorophyll $a$ values were again found when appreciable quantities of nanoplankton were also present. The occurrence of ultrananoplankton (Fig. 3 A) appears to be rather sporadic, but there is some indication that maxima in the biomass of this size group were present towards the end of the nanoplankton and microplankton blooms.

Table 1 shows the relationship between the total volume of particulate material in two size fractions and the amount of particulate carbon and chlorophyll. The relationships reported for nanoplankton were obtained from 20 samples 
Table 1. Relationships between volume of particulate material, chlorophyll $a$ and organic carbon.

\begin{tabular}{|c|c|c|c|c|}
\hline & $\begin{array}{l}\text { Number of } \\
\text { samples }\end{array}$ & $\mathrm{r}$ & $\begin{array}{l}\text { Level of } \\
\text { significance }\end{array}$ & Regression equation \\
\hline \multicolumn{5}{|l|}{ Microplankton } \\
\hline $\begin{array}{l}\text { Coulter volume* } \\
\text { vs carbon* }\end{array}$ & 23 & 0.74 & 0.01 & Particles $=15.9 \pm 2.2$ Carbon $-2.9 \pm 1.2$ \\
\hline $\begin{array}{l}\text { Coulter volume* } \\
\text { vs chlorophyll } a^{*} \\
\text { Nanoplankton }\end{array}$ & 23 & 0.45 & 0.05 & Particles $=1000 \pm 190 \mathrm{Chl} a-1.2 \pm 0.3$ \\
\hline $\begin{array}{l}\text { Coulter volume* } \\
\text { vs carbon* }\end{array}$ & 20 & 0.71 & 0.01 & Particles $=7.4 \pm 0.6$ Carbon $-1.4 \pm 0.2$ \\
\hline $\begin{array}{l}\text { Coulter volume* } \\
\text { vs chlorophyll } a\end{array}$ & 20 & 0.69 & 0.01 & Particles $=295 \pm 48 \mathrm{Chl} a-0.9 \pm 0.3$ \\
\hline
\end{tabular}

collected during May, the size spectra for this time indicating that nanoplankton were the predominant phytoplankton present. Similarly the relationships for microplankton are for 23 samples taken in June when microplankton were the predominant organisms. The correlation of particulate volumes with carbon and chlorophyll $a$ were highly significant except in the case of microplankton and chlorophyll, where the significance of the relationship was only valid at the $\mathrm{P}=.05$ level. The regression equations, determined as the reduced major axes and showing the standard error of the intercept and the slope, indicate that the nanoplankton contained approximately twice as much organic carbon and about three times as much chlorophyll $a$ per unit volume as did the microplankton.

Primary productivity: Fig. 4 shows changes in the rate of primary production at $0 \mathrm{~m}$ as measured by an increase in particle volume in two plankton size fractions (Fig. 4B) and by the ${ }^{14} \mathrm{C}$-method (Fig. $4 \mathrm{~A}$ ). From these data it may be seen that on the 17 th May, there was a decrease in the cellular volume of the microplankton during a 24-hour incubation, but that the nanoplankton increased in volume. The reverse was true on the 4 th July. On the 22 nd June, however, both nanoplankton and microplankton showed a marked increase in volume and this coincided with a large maximum in the uptake of ${ }^{14} \mathrm{CO}_{2}$ (Fig. $4 \mathrm{~A}$ ). In general, however, changes in cellular volume of nano- and microplankton did not coincide, and peaks in the carbon-14 production shown in Fig. $4 \mathrm{~A}$ repre-

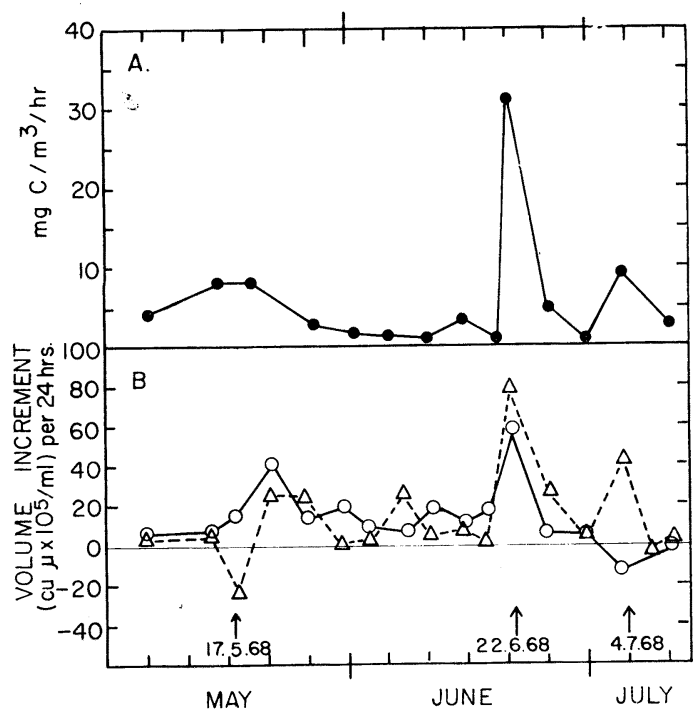

Fig. 4. Primary production at $0 \mathrm{~m}$, May $\sim$ July, 1968, measured by (A) uptake of $\mathrm{CO}_{2}$ and (B) changes in cellular volume (- uptake of $14-\mathrm{CO}_{2} ; \bigcirc-\bigcirc$ changes in nanoplankton volume; $\triangle-\triangle$ changes in microplankton volume).

sented combinations of different levels of productivity which occurred in the two size fractions, including measurements of negative production by the particle volume technique which were not measured by use of the carbon-14 technique.

Fig. 5 shows changes in the actual rate of production on certain days which have been chosen as illustrating the different types of production occurring during the study period. Thus from measurements over a 24-hour period, the 


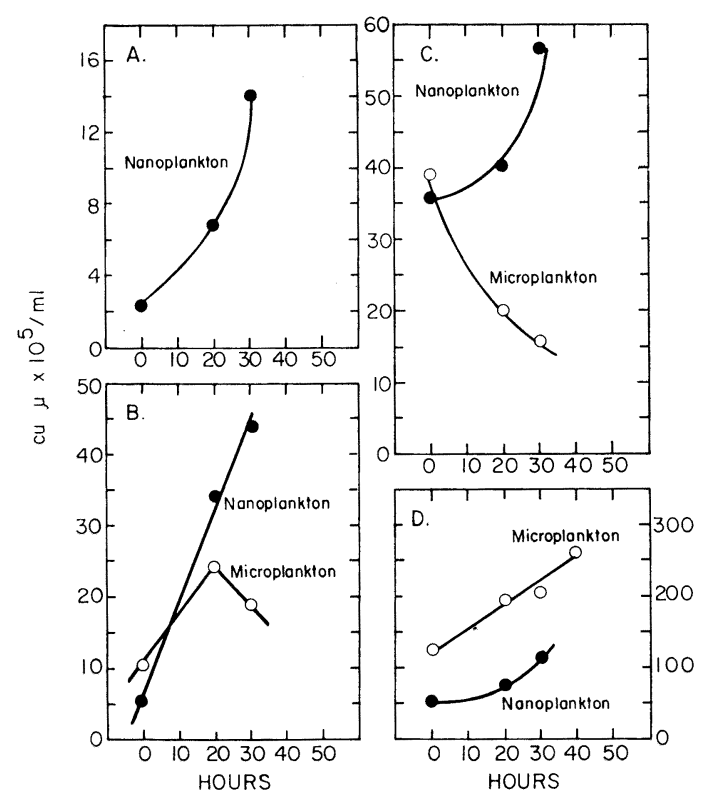

Fig. 5. Some representative growth curves for nano- and microplankton.
(A) $5 \mathrm{~m}, 2$ June
(B) $5 \mathrm{~m}, 9$ May
(C) $0 \mathrm{~m}, 17$ May
(D) $0 \mathrm{~m}, 22$ June

most rapid production, in terms of the time required for the population to double, was approximately 9 hours at $5 \mathrm{~m}$ on the 9 th May and 11 hours at $5 \mathrm{~m}$ on the 2nd June (Fig. $5 \mathrm{~B}$ and A respectively). Both of these high production rates involved the growth of nanoplankton. However, the greatest quantity of phytoplankton produced over a 24-hour period was by the microplankton at $0 \mathrm{~m}$ on 22nd June (Fig. $5 \mathrm{D}$ ). The actual generation time of this population was about 38 hours and, in general, the generation times of the microplankton were greater than 30 hours, although one observation was made of a 12.5-hour generation time. Fig. $5 \mathrm{C}$ shows the situation, which occurred at $0 \mathrm{~m}$ on 17th May, of a nanoplankton bloom increasing while the microplankton decreased.

Plankton diversity: Fig. 6 shows differences in the size spectra of nanoplankton on four days at $0 \mathrm{~m}$. The data are from Fig. 2 but have been redrawn as histograms so that the total volume of particulate material in each of the ten nanoplankton size categories is more apparent. From these values the amount of particulate material in any one size category was expressed

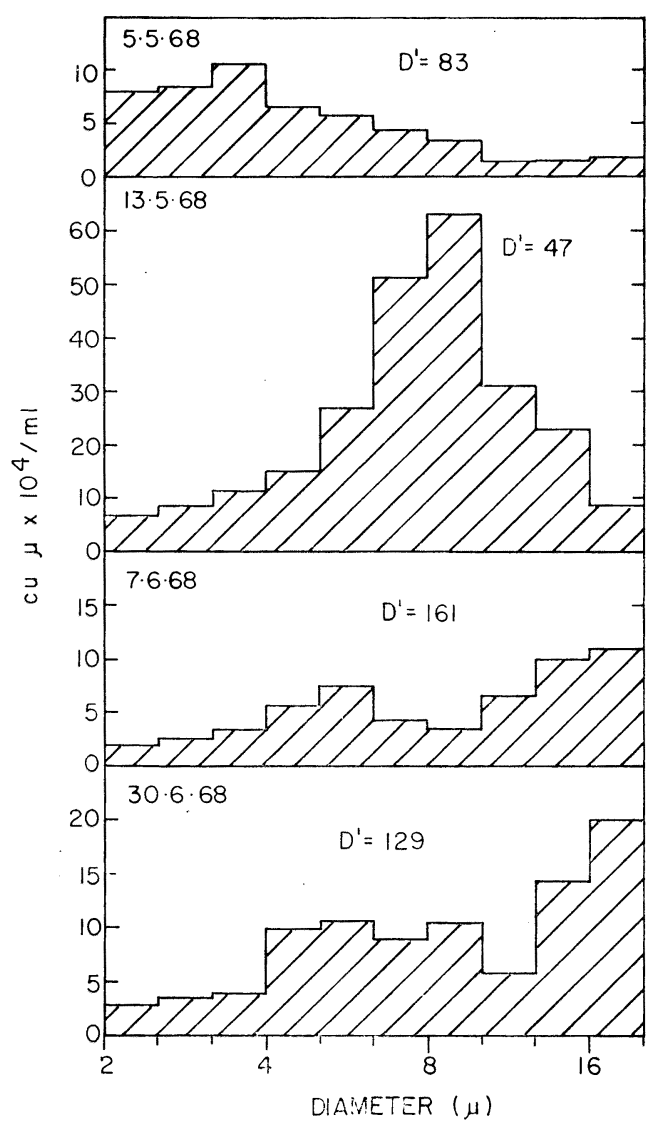

Fig. 6. Particle size spectra and diversity at $0 \mathrm{~m}$ in Saanich Inlet on selected days (Data from Fig. 2).

as a fraction $\left(p_{i}\right)$ of the total nanoplankton volume, and the diversity index $(D)$ of the nanoplankton was determined for the four spectra, using the expression (SHANNON, 1948)

$$
D=-\sum p_{i} \log _{\epsilon} p_{i}
$$

which for convenience has been shown in Fig. 6 as $D^{\prime}=100(D-2)$.

The actual species of phytoplankton responsible for the observations reported in Fig. 2 to 6 were not studied in detail, but during the middle of May the predominant phytoplankton were small flagellates (possibly Chrysophyceae) and during the large microplakton bloom in June, diatoms of the species Skeletonema costatum, Thalassiosira rotula and Rhizosolenia stolterfothii were particularly abundant. 


\section{Discussion}

The use of diversity indices in describing the structure of a community has found some application among marine planktologists (e.g. HULBERT et al., 1960) but much wider use among terrestrial ecologists (e. g. see ODUM et al., 1960 for a partial summary). The value of a diversity index, from a practical point of view, is that it allows the reduction of a large amount of data on the number of species and total number of organisms to a single number, which can then be employed in the same way as data on production, temperature and nutrients might be used to define a particular volume of water. From a theoretical point of view an index of diversity can be used to describe a plankton community in terms of the stability of its food chain and the probability of a particular predator encountering a particular prey. One shortcoming of a diversity index based on species alone is that species may change their biomass after a period of time, without changing their numerical composition. A modified diversity index, which took into account the reproductive rate of individuals, was suggested by LLOYD (1964). WILHM (1968) has suggested biomas units, and possibly energy units, as another solution to this problem. As can be seen from Fig. 6. the use of biomass units (nanoplankton expressed as cu $\mu / \mathrm{m} l$ ) is particularly applicable to the case of size spectra. When the value $D^{\prime}$ is used to describe changes in the shape of the spectrum, the events which occurred from the beginning of May to the end of June are found to be very similar to the description of species succession given by MARGALEF (1958) for a coastal phytoplankton community. Thus, before the first nanoplankton bloom, there was a relatively high index of diversity due to the mixture of plankton from different water masses $\left(D^{\prime}=83,5\right.$ May); when the first bloom developed in a relatively well mixed water column (Fig. 1), there was a drop in diversity ( $D^{\prime}=47,13$ May), followed by an increase $\left(D^{\prime}=161\right)$ as the water mass stabilized. Finally, after a microplankton bloom had developed (Fig. 2), a second nanoplankton bloom occurred, but the diversity of this bloom was considerably greater $\left(D^{\prime}=129\right)$ than the earlier nanoplankton bloom in May. This latter bloom was caused by a polymictic group of flagellates, which, according to MARGALEF (1958), probably had more exacting nutritional requirements than the flagellates which occurred in May.

Particulate material in the ultrananoplankton size category $(<2 \mu$, Figs. 2 and 3$)$ has been discussed previously (PARSONS and SEKI, 1969a). It appears that this size group is predominated by heterotrophic organisms such as bacteria, yeasts and very small flagellates. In the case of bacteria and yeasts it was shown (PARSONS and SEKI, 1969a) that these occurred in Saanich Inlet in very large numbers at the end of a phytoplankton bloom. Furthermore it appears that there is a process of particle aggregation involved in this size group of organisms and this is caused by certain species of bacteria which have a high tendency to clump. Consequently, particles which are first detected in the ultrananoplankton size category, tend to move up in to the nanoplankton size group as aggregation proceeds.

Data on the carbon content per unit volume of nano- and microplankton (Table 1) are in general agreement with the data given by STRATHMANN (1967). Thus, in the case of nanoplankton ( $c a$ $8 \mu$ diameter, Fig. 1), if the ratio of cell volume to carbon is compared with the ratio cell volume to carbon for phytoplankton other than diatoms (Fig. 4, StrathmanN, loc. cit.), then from Strathmann's data the value would be $6.7 \mathrm{com}$ pared with $7.4 \pm 0.6$ in Table 1 . When the same estimate is made for the microplankton (diameter ca $40 \mu$ ), which was composed predominately of diatoms, the cell volume to carbon ratio is approximately 34 (Fig. 2, STRATHMANN, loc. cit.), compared with $15.9 \pm 2.2$ in Table 1 . Although the former figure is twice the latter, this is in fact still a reasonable agreement with the data reported by STRATHMANN, which cover a range of cell volumes and carbon contents of six orders of magnitude. The reason for this wide range of values has been attributed to the size of the cell vacuole which generally increases with increased cell volume, especially in diatoms. This may also explain the difference in the ratios of cell volume to chlorophyll $a$, which are also reported in Table 1 for nano- and microplankton. However, the three-fold increase in chlorophyll $a$ content of nanoplankton compared with micro- 
plankton may also be in part a function of the reaction of phytoplankton to different light intensities. In this respect the average light intensity in the mixed layer during May was approximately $0.012 \mathrm{ly} / \mathrm{min}$, and during June, $0.029 \mathrm{ly} / \mathrm{min}$ (for method of calculation, see PARSONS et al., 1969). NIELSEN et al. (1962) showed that a difference in light intensity of this order produced an approximate doubling in the chlorophyll a content of Chlorella vulgaris cells, and it may be reasonable to extrapolate this result to explain in part the different cell volume to chlorophyll $a$ ratios reported in Table 1 .

In summary of these discussions, I have presented some data on size spectra which were obtained at the same time as data obtained by established techniques for measuring plankton biomass, production and diversity. The result of this comparison has shown that the use of particle size spectra generally gives more information than is available by the use of these techniques (e.g. $\mathrm{C}^{14}$ production), and that the method is easier to apply than certain other techniques (e.g. species identification). At the same time, when particle size spectra are used to obtain a description of phytoplankton blooms, or of carbon and chlorophyll to cell volume ratios, the data reported are comparable to those obtained by more traditionally accepted techniques.

\section{Conclusions}

In order to describe the structure of a plankton community, data must be obtained on both the complexity of the community, and on the relationship of the individual components to each other. Data on total biomass and production can be obtained by conventional biological oceanographic techniques but these data are not sufficient to describe the structure of a community. Taxonomic data can be used to describe the complexity of a plankton population but the limitation with this approach is the time and effort required to obtain the data. In addition, taxonomy alone does not quantify the dynamic relationships which may exist between various components of the plankton, including both primary and secondary producers. In contrast to conventional approaches in the study of plankton communities, the particle size spectrum is sug- gested as a unified approach, involving a single technique, from which it is possible to obtain data on both the production and complexity of plankton communities. The former can be measured in terms of absolute units of biomass produced per unit time by individual size components of the plankton, and the latter can be measured by employing an expression of diversity. In addition, the relationship between two trophic levels within a community can be examined (e. g. see PARsons et al,, 1967).

\section{References}

Allen, W. E. (1922): Quantitative studies on inshore marine diatoms and dinoflagellates of southern California in 1920. Univ. Calif. Publ. Zool. 22: 369-378.

Atkins, W. R. G.I(1923): The silica content of some natural waters and culture media. Jour. Mar. Biol. Assoc. U. K. 13, 151-159.

Cleve, P. T. (1883); Diatoms collected during the expedition of the "Vega". Vega-Exped. Vetense. Arbet. Iakttag. 3, 457-517.

Conover, R. J. (1966): Assimilation of organic matter by zooplankton. Limnol. Oceanogr., 11, 338-345.

DussarT, B. M. (1965): Les différentes catégories de plancton. Hydrobiologia, 26, 72-74.

FLEMING, R. H. (1939): The control of diatom populations by grazing. Jour. Cons. int. explor. Mer, 14. 3-20.

Hairston, N. G. (1959): Species abundance and community organization. Ecology, 40, 403-416.

HARVEY, H. W. (1928): Nitrate in the sea. Jour. Mar. Biol. Assoc. U. K., 15, 183-190.

HERLINVEAUX, R. H. (1962): Oceanography of Saanich Inlet in Vancouver Island, British Columbia. Jour. Fish. Res. Bd. Canada, 19, 1-37.

Hulbert, F. M., J. H. Ryther and R. R. L. GuilLARD (1960): The phytoplankton of the Sargasso Sea off Bermuda. Jour. Cons. intern. explor. Mer, 25, 115-128.

Karsten, G. (1905): Das Phytoplankton des Antarktischen Meeres nach dem Material der deutschen Tiefsee-Expedition, 1898-1899. Wissenschaftliche Ergebnisse der deutschen Tiefsee-Expedition auf dem Dampfer "Valdivia" 2, 1-136.

LLOYD, M. (1964): Weighting individuals by reproductive value in calculating species diversity. Amer. Nat., 98, 190-192.

MARGalef, D. R. (1957): La teoria de la informacion en ecologia. Mem. Real. Acad. Ciencias y Artes de Barcelona, 32, 373-449. (Translation 
by Wendell Hall, General Systems, Year-book, 3, 36-71, 1957).

MARGalef, D. R. (1958): Temporal succession and spatial heterogeneity in phytoplankton. Perspectives in Marine Biology Ed. A. A. BuzzatiTraverso, Univ. Calif. Press, 323-349.

MARgalef, D. R. (1965): Ecological correlations and the relationship between primary productivity and community structure. Mem. Ist. Ital. Idrobiol., 18, (Suppl.) 355-364.

Margalef, D. R. (1968): Perspectives in Ecological Theory. Univ. Chicago Press, p. 111.

MiYAKE, Y. (1939): Chemical studies of the Western Pacific Ocean. Bull. Chem. Soc. Japan, 14, 29-35.

Odum, H. T., J. E. CANTLON and L. S. Kornicker (1960): An organizational hierarchy postulate for the interpretation of species-individual distributions, species entropy, ecosystem evolution, and the meaning of a species-variety index. Ecology, 41, 395-399.

Parsons, T. R., R. J. LeBrasseur and J. D. FULTON (1967): Some observations on the dependence of zooplankton grazing on the cell size and concentration of phytoplankton blooms. Jour. Oceanogr. Soc. Japan, 23, 10-17.

PARSONS, T. R., K. STEPHENS and R. J. LEBrasSEUR (1969): Production studies in the Strait of Georgia I. Primary production under the Fraser River plume, February to May, 1967. Jour. Exp. Mar. Biol. Ecol., 3, 27-38.

PARSONS, T. R. and H. SEKI. (1969a): Importance and general implications of organic matter in aquatic environments. Symposium on "Organic Matter in Natural Waters". College, Alaska. Ed. D. Hood. (In press).

PARsons, T. R. and H. SEKI (1969b): A short review of some automated techniques for the detection and characterization of particles in sea water. Fish. Oceanogr. (Prof. Uda Memorial Volume). (In press)

PATten, B. C. (1959): An introduction to the cybernetics of the ecosystem: the trophic-dynamic aspect. Ecology, 40, 221-231.

Patten, B. C. (1961): Negentropy flow in communities of plankton. Limnol. Oceanogr., 6, 26-35.

RAKESTRAW, N. W. (1936): The occurrence and significance of nitrite in the sea. Biol. Bull. Woods Hole, 71, 133-167.

Riley, G. A. (1947): A theoretical analysis of the zooplankton population of Georges Bank. Jour. Mar. Res., 6, 104-113.

SHANNON, C. E. (1948): A mathematical theory of communication. Bell Syst. Tech. Jour., 27, 379$423,623-656$.

Sheldon, R. W. and T. R. PARsons (1967a): A practical manual on the use of the Coulter Counter in marine science. Coulter Electronics Sale; Co.Canada, p. 66.

Sheldon, R. W. and T. R. PARsons (1967b): A continuous size spectrum for particulate matter in the sea. Jour. Fish. Res. Bd. Canada, 24, 909-915.

SHEldon, R. W., T. P. T. Evelyn and T. R. PARSONS (1967): On the occurrence and formation of small particles in seawater. Limnol. Oceanogr., 12, 367-375.

Shiraishi, K. and L. Provasoli (1959): Growth factors as supplement to inadequate algal foods for Tigriopus japonicus. Tohoku G. Agr. Res., 10, 89-96.

Steele, J. H. (1958): Plant production in the northern North Sea. Sci. Invest. Ser., Mar. Res. No. 7, Fish. Bd. Scotland, U. K., p. 36.

SteEman Nielsen, E. (1952): The use of radioactive carbon $\left(\mathrm{C}^{14}\right)$ for measuring organic production in the sea. Jour. Cons. int. explor. Mer, 18, 117-140.

Steeman Nielsen, E., V. K. Hansen and E. G. J $\phi_{\text {RGENSEN (1962): The adaptation to different }}$ light intensities in Chlorella vulgaris and the time dependence on transfer to a new light intensity. Physiol. Plant., 15, 505-517.

Stephens, K., J. D. FULTON and O. D. KenNedy (1969): Summary of biological oceanographic observations in the Strait of Georgia, 1965-1968. Tech. Rept., Fish. Res. Bd. Canada. (In press)

StRathmanN, R. R. (1967): Estimating the organic carbon content of phytoplankton from cell volume or plasma volume. Limnol. Oceanogr., 12, 411418.

STrickland, J. D. H. and T. R. PARsons (1968): A practical handbook of seawater analysis. Bull. 167, Fish. Res. Bd. Canada, p. 311.

SVERdRUP, H. V., M. W. JOHNSON and R. H. FlemING (1946): The Ocean- their physics, chemistry and general biology. Prentice-Hall Inc., New York, p. 1087.

WilHM, J. L. (1968): Biomass units versus numbers of individuals in species diversity indices. Ecology, 49, 153-156. 


\section{プランクトン群集構造解析のための粒径 スペクルの利用}

T. R. PARSONS

要旨 初期のプランクトン研究はほとんど記述的分類学 に限られていた．その後，プランクトンの定量的測定が 化学的に可能となり, これによって得たデータはプラン クトン群集動態の数学 モデル化の資料に用いられてい る. 最近, プランクトン研究に新しい考えを加える必要 を MARGALEF (1957), PATTEN（1959）などが提唱し
ている．観念的にはプランクトン群集の構成又は構造を 依存しあうすべての種類の相互作用で示すことである. 実際上, 問題は分類学的見地に遍重することなく, 群集 構造の適切な定量的表示を得ることである. 本論文では 生物生産モデルやプランクトン群集構造解析の資料を得 る方法として, 粒径スペクトルの利用について論ずる. 